\title{
Push and Pull Factors of Transnational Street Begging in South Western Nigeria

\author{
DOI: 10.36108/NJSA/5102/13(0220)
}

\author{
Usman Adekunle Ojedokun* \\ Adeyinka Abideen Aderinto \\ Department of Sociology \\ Faculty of the Social Sciences \\ University of Ibadan, Ibadan, Nigeria \\ *Corresponding Author: uaojedokun@gmail.com
}

\begin{abstract}
Street begging in Nigeria has traditionally been dominated by indigenous beggars. However, a growing trend in the phenomenon in recent times is the involvement of migrant beggars in streets. Against this background, this paper examined the push and pull factors of transnational street begging in South Western Nigeria. The study was exploratory and cross-sectional in design. Anomie-strain theory was adopted as conceptual framework. Convenience and purposive sampling techniques were employed to select 395 respondents. Survey questionnaire and in-depth interview were the methods of data collection. Transnational street beggars attributed their involvement in street begging to different socio-economic and environmental challenges in their home-countries. Most of them (53.4\%) migrated to Nigeria for better opportunity. The Federal Government of Nigeria is urged to put in place a mechanism through which refugees who are genuinely in need can be helped and/or distinguished from migrants who have permanently taken to street begging as their means of livelihood.
\end{abstract}

Keywords: street begging, transnational street begging, migrant beggars, push and pull factors, South Western Nigeria

\section{Background}

In recent times, the problem of street begging has assumed an international dimension (The Punch, 2012; Cherneva, 2011). In Nigeria, street begging has traditionally been dominated by indigenous beggars. However, a growing trend in the phenomenon, today, is the large scale involvement of transnational street beggars in the activity. A large number of migrant beggars from some neighbouring African countries has taken to street begging in nearly all the major urban centres in Nigeria (Adedibu and Jelili, 2012; Adedokun, 2003).

Though street begging is conceived as a deviation from what Nigeria and the majority of her citizens define as right (Adewuyi, 2000), the severity and widespread nature of this problem are exemplified by different categories of persons engaging in it (Fawole, Ogunkan and Omuruan, 2011; Ibrahim, 1997). While some people take to begging as a permanent business, others see it as a temporary measure to escape from their poverty conditions. Some other 
individuals engage in begging as a way of diverting the attention of people from some evil they may want to perpetrate (Adedibu and Jelili, 2011).

Different reasons account for people's involvement in street begging. Lynch (2005) recognizes begging as a complex and multi-faceted problem that is most often caused by multiple and interrelated individual and structural deprivations. The National Council for the Welfare of the Destitute (2001) identifies six reasons why people engage in begging in Nigeria to include loss of parental/guardian support, parental/guardian neglect, poverty, disability, socio-cultural misconceptions and lack of parental education. Similarly, Igbinovia (1991) summarizes factors promoting street begging in Nigeria to include traditional and cultural factors, customs and religion, poverty and destitution, laziness and indolence, unemployment and the need to make a living or money, deformity and disability, desertion and lack of spouse or family care, inadequate or lack of rehabilitation and vocational centers, old age, influx of illegal and destitute aliens.

To Demewozu (2005), poverty is the most reported precipitating factor of street begging in the society which finds expression in scarcity of resources needed to lead a normal life. Osagbemi and Adepetu (1999) implicated modernization and western influence as factors promoting street begging in Nigeria because they are increasingly leading to the disappearance of the extended family support system which in the past characterized most African societies. Furthermore, Adedibu and Jelili (2011) view urban land use activities as important factor influencing the spatial distribution of beggars in Nigerian cities. Hence, begging activities in the country are more concentrated in commercial, public and high density urban environments.

In a study conducted in Australia by Cooke and Horn in 2001, some of the reasons given by the respondents for engaging in begging were discovered to be related to their life histories and the pressure their past disadvantage and trauma had placed upon them. To Ahmadi (2010), begging is a social problem that not only has psychological consequences, such as the development of inferiority complex in the beggars' family members and their network of kinship, but also affects the geographical and social structure of cities.

Transnational street-begging has become a major problem in Nigeria because it is negatively rubbing off on the socio-economic wellbeing of the country. Apart from the fact that it is aggravating the problem of street begging in Nigeria, transnational street beggars, like their local counterparts, can also be used by mischief makers to perpetrate violence and/or vandalize public property (Ojedokun, 2015). Recently, some migrants from neighbouring African countries were indicted by the Nigerian security agencies as members of Boko Haram, the terrorist group that is threatening the corporate existence of the country. Also, research in some other parts of the world has revealed that a strong relationship exists between organized human trafficking network and transnational street begging (Cherneva, 2011; Friends-International and UN Inter-Agency Project, 2006). In addition, the sheer number of children 
soliciting alms on the street alongside adult transnational beggars in most of the major urban centres in Nigeria is increasingly becoming worrisome.

In spite of the fact that transnational street beggars constitute an integral part of the people soliciting alms on the streets of major urban centres in Nigeria, sufficient scholarly attention has not been devoted to this category of beggars as a distinct group. Therefore, the central objective of this study is to examine the push and pull factors of transnational street begging in South Western Nigeria.

\section{Theoretical Background}

The push and pull factors of transnational street begging in South Western Nigeria were examined within the framework of anomie-strain theory. Robert K. Merton proposed this theory after reviewing Emile Durkheim's theory of anomie. The theory opines that culture of any society defines certain goals it deems "worth striving for", and also specifies the approved norms or institutionalized means all individuals are expected to follow in pursuing the cultural goals (Vold and Bernard, 1986). However, due to social inequality, the approved means to reach the success goals are not readily available to certain groups of people in the society. According to Merton, when this inequality exists because of the way the society is structured, the social structure is anomic (Williams and McShane, 1999). The individuals caught in these anomic conditions (largely the lower class) are then faced with the strain of being unable to reconcile their aspirations with their limited opportunities. Merton presents five ways by which an individual can respond to this problem depending on his attitude towards the cultural goals and the institutionalized means. These options are conformity, innovation, ritualism, retreatism and rebellion (Vold and Bernard, 1986).

To the extent that a society is stable, most persons in it will choose 'conformity', which entails acceptance of both the cultural goals and institutionalized means. Most crimes that exist in society, however, will probably take the form of 'innovation'. Persons who innovate retain their allegiance to the cultural goal of acquiring wealth, but figure out new methods by which wealth can be acquired. A third possible adaptation is ritualism which involves rejecting the possibility of ever achieving wealth, but retaining allegiance to the norms of hard work and honesty. The fourth adaptation, retreatism, involves a rejection of both goals and means set by the society. These individuals have simply quit trying to get ahead. The final mode of adaptation, 'rebellion' is of a different type from the others. It focuses on the substitution of new goals and means for the original ones (Williams III and McShane, 1999). Transnational street beggars like their local counterparts, the Nigerian beggars, fall within the category of persons that adopt innovation as their mode of adaptation to the strain conditions existing in their societies. 


\section{Research Settings and Methodology}

The study was exploratory and cross-sectional in design. It was conducted in South Western geo-political zones of the country. This area is mainly inhabited by the Yoruba people. The National Population Census conducted in 2006 estimated the total population size of the inhabitants of South Western Nigeria to about 27, 581,993 (Federal Republic of Nigeria Official Gazette, 2007). This location was selected for this study because of the prevalence of street begging in the area (Adedibu and Jelili, 2011; Federal Office of Statistics, 2001).

The study population comprised both male and female transnational street beggars conducting street begging in South Western Nigeria. With regard to sampling, two major urban centres in the South-West, Lagos and Ibadan, were purposively because of the presence of transnational street beggars on their major streets. Also, convenience and purposive sampling techniques were employed for the selection of 395 transnational street beggars. This approach was basically adopted because of the mobile nature of the study population. Data were essentially collected through the triangulation of quantitative and qualitative methods. A set of 382 copies of a semi-structured questionnaire was administered on the transnational street beggars through face to face interview.

In addition, 13 in-depth interviews were also conducted with some purposively chosen respondents who possessed some unique information on the subject of study, as a way of complementing the survey. All qualitative data were conducted with the aids of tape recorder and field note. At each of the purposively selected cities, transnational street beggars were strategically sourced in their favoured locations; and Fridays were essentially reserved for data collection at popular central mosques where beggars usually converge in large numbers. The assistance of local people, who were observed to have established some form of relationship or familiarity with some of these beggars, was also sought at different times to help allay their fears.

Also, the service of a field assistant who is fluent in spoken and written Hausa language was employed for the easy conduct of the fieldwork in case some of the respondents found it difficult to communicate effectively in either English or Yoruba Language. However, nearly all the interviews conducted were done using either of these two languages because the respondents remarkably demonstrated a good understanding and speaking of either one, or both of them. Data generated through the administered questionnaire were processed and analysed using frequency distribution, cross-tabulation and chisquare statistics. Moreover, the qualitative data were processed through content analysis and ethnographic summaries which involved a careful transcription, detailed description and interpretation of the tape-recorded data and field-note.

\section{Results and Discussion}

Table 1 presents the socio-demographic characteristics of the respondents. The sex distribution of respondents indicates that female constituted $56.3 \%$ of the respondents, while male constituted $43.7 \%$. As regards age, respondents who 
were between the ages of $15-19$ were the most represented $(26.4 \%)$, while those who were between the ages 35-39 (19.9\%), and those who fell between the ages $30-34(18.6 \%)$ were also fairly represented. Also, about $14 \%$ of the respondents were between the ages 20-24, while those who were between the ages of 25-29 constituted $11.5 \%$. The preponderance of children among them can be explained as resulting from the fact that alms-givers are more easily moved to give charity to children than adults. Hence, the children were being used by their adult counterparts to make more money. Furthermore, the table indicates that transnational street beggars from Niger Republic (79.6\%) were in the majority, followed by those from Chad Republic (15.2\%), the nationals of Mali had the lowest frequency (5.2\%). This implies that transnational street beggars were citizens of some neighbouring West African countries that are relatively poorer when compared to Nigeria in terms of physical, social and economic resources.

Similarly, the religion of the majority of the respondents $(91.3 \%)$ was Islam, while $6.3 \%$ of them stated that they were adherents of Traditional religion; the remaining $2.4 \%$ of them mentioned Christianity as their religion. Their marital status distribution reveals that the majority $(61.8 \%)$ of the respondents were married, followed by those who were single (33.0\%); few of them $(3.1 \%)$ were widowed and very few of them $(2.1 \%)$ were divorced. The table further indicates that respondents who had between 1-3 children were the largest $(36.6 \%)$ in proportion, followed by those who had between 4-6 children (28.8\%); about $28 \%$ of them had no child. In addition, most of the respondents $(64.4 \%)$ claimed to have resided in Nigeria for less than a year, while about $12 \%$ reported that they had been living in the country for 3years. The recorded small proportion of respondents who had taken residence in Nigeria for a period of 2 years and above was not unexpected because of the mobile nature of transnational street beggars. Also, the majority (47.1\%) of the respondents had no formal education, but those who had acquired Arabic education were also substantially represented (36.1\%), few of them (13.6\%) had primary education and very few of them $(1.0 \%)$ had secondary education. The analysis of respondents' means of livelihood in their home-countries shows that the majority $(28.2 \%)$ were farmers, while $24.9 \%$ were pastoralist. Also, those who combined farming with pastoralism were also fairly represented (19.1\%); about $14 \%$ were artisans.

\section{Reasons for Leaving Home-Country}

To gain insight into the factors predisposing transnational street beggars to alms solicitation in Nigeria, the reasons responsible for their emigration from their country of origin was investigated. The reasons given by them are presented in table 2. 
Table 2: Reasons for Leaving Home-Country

\begin{tabular}{|c|c|c|c|c|c|}
\hline \multirow[b]{2}{*}{ Nationality } & \multicolumn{4}{|c|}{ Reasons for leaving home-country } & \multirow[b]{2}{*}{ Total } \\
\hline & Drought & Famine & $\begin{array}{l}\text { Poverty \& } \\
\text { War }\end{array}$ & $\begin{array}{l}\text { Drought\& } \\
\text { Famine }\end{array}$ & \\
\hline \multirow[t]{2}{*}{ Nigerien } & 81 & 117 & 54 & 52 & 304 \\
\hline & $26.6 \%$ & $38.5 \%$ & $17.8 \%$ & $17.1 \%$ & $100.0 \%$ \\
\hline \multirow[t]{2}{*}{ Chadian } & 31 & 11 & 11 & 5 & 58 \\
\hline & $53.4 \%$ & $19.0 \%$ & $19.0 \%$ & $8.6 \%$ & $100.0 \%$ \\
\hline \multirow[t]{2}{*}{ Malian } & 7 & 3 & 8 & 2 & 20 \\
\hline & $35.0 \%$ & $15.0 \%$ & $40.0 \%$ & $10.0 \%$ & $100.0 \%$ \\
\hline \multirow[t]{2}{*}{ Total } & 119 & 131 & 73 & 59 & 382 \\
\hline & $31.2 \%$ & $34.3 \%$ & $19.1 \%$ & $15.4 \%$ & $100.0 \%$ \\
\hline
\end{tabular}

$\chi^{2}=26.568 ; d f=6 ; P=0.000$

Table 2 indicates that most (38.5\%) of the Nigeriens linked their reason for leaving their country of origin to famine. Close to $27 \%$ identified drought as responsible for their decision to emigrate, while about $18 \%$ identified poverty and war. Less than $18 \%$ stated that they left their country due to drought and famine. Unlike their Nigerien counterparts, a large proportion of Chadians $(53.4 \%)$ claimed that they left their home-country as a result of drought; and $19.0 \%$ each attributed the causes of leaving their country to famine and poverty and war. However, close to $9 \%$ opined that they left their country due to famine and drought. For the Malian transnational street beggars, the majority $(40.0 \%)$ claimed that they left their country because of poverty and war, while $35.0 \%$ identified drought. Also, $15.0 \%$ attributed the cause of leaving their country to famine, and very few of them $(10.0 \%)$ declared that drought and famine were their reasons for leaving. The difference in the factors identified as causing their emigration according to nationality was reflected in the significant value of the chi-square $\left(\chi^{2}=26.568 ; \mathrm{P}<0.05\right)$ in table 2 .

Generally, the major reasons identified by the respondents as informing their decision to leave their respective home countries included famine (34.3\%), drought $(31.2 \%)$ and poverty and war (19.1\%). The outcome of the in-depth interview also supported the survey. One of the respondents interviewed stated:

We had to leave Niger Republic because there was severe drought and famine in our land. All our animals have died and our farmlands are bad; only birds now occupy our villages. Everybody has left because we do not want to die of hunger and thirst. If you do not believe me, you can check this (he brought out a mobile phone from his pocket and showed us this website: 
www.tnrewl.com which could not be accessed). (Nigerien Male Transnational Street Beggar/IDI/Kara, Ibadan)

The above respondent's submission has clearly reflected the precarious condition that some of the transnational street beggars, particularly those from Niger Republic, were exposed-to in their country before coming to Nigeria. They lost their domestic animals and farmlands to drought. However, to reduce the social stigma that is usually associated with street begging, he was quick to support his claim by presenting a website that purportedly reports the situation of his country.

In the words of another respondent:

I had to leave my country with my children because things became very difficult after the death of my husband. The drought and famine problems that also ravaged Chad at that time did not help because we did not have food to eat and that is why we decided to come here for survival. (Chadian Female Transnational Street Beggars/IDI/ Ajegunle, Lagos)

The account of the respondent above indicates that multiple problems, including drought and famine in her country of origin (Chad Republic), as well as the death of her husband were responsible for her decision to migrate with her children to Nigeria for the purpose of taking to street begging.

It has been established from the above findings that different factors were responsible for the emigration of the respondents. These findings are in consonance with Veale's (1993) submission that several factors such as the failure of rural livelihoods, displacement due to drought, famine, war, harmful traditional practices and uncaring environments at home can force people into begging. Afolayan, Ikwuyatum and Abejide (2010) have also contended that the decision of people to move out of a location is often determined by different socio-economic inadequacies (push factors) that include lack of employment opportunities and lack of access to better life existing in the source region, but which are believed to be available (pull factors) in choice destinations. The decision of transnational street beggars to migrate to Nigeria for the purpose of alms solicitation validate the proposition of anomie-strain theory which states that certain group of people responds to strain condition resulting from the disjuncture between the societal goal and institutionalized means by innovating new ways of reconciling their aspirations with their limited opportunities.

\section{Reasons for the Choice of Nigeria as Country of Destination}

The pull factors that attracted transnational street beggars to Nigeria were also investigated. This was accomplished by examining the reasons that informed 
their choice of Nigeria as their country of destination. Table 3 depicts the four major reasons given by the respondents as influencing their choice of Nigeria.

Table 3: Reasons for the Choice of Nigeria by Nationality

\begin{tabular}{|c|c|c|c|c|c|}
\hline \multirow[b]{2}{*}{ Nationality } & \multicolumn{4}{|c|}{ Reasons for the choice of Nigeria } & \multirow[b]{2}{*}{ Total } \\
\hline & $\begin{array}{l}\text { Nearness to } \\
\text { my country }\end{array}$ & $\begin{array}{l}\text { Better } \\
\text { opportunity }\end{array}$ & $\begin{array}{l}\text { Presence of } \\
\text { contacts }\end{array}$ & $\begin{array}{l}\text { I like } \\
\text { Nigeria }\end{array}$ & \\
\hline \multirow[t]{2}{*}{ Nigerien } & 44 & 162 & 76 & 22 & 304 \\
\hline & $14.5 \%$ & $53.3 \%$ & $25.0 \%$ & $7.2 \%$ & $100.0 \%$ \\
\hline \multirow[t]{2}{*}{ Chadian } & 3 & 34 & 13 & 8 & 58 \\
\hline & $5.2 \%$ & $58.6 \%$ & $22.4 \%$ & $13.8 \%$ & $100.0 \%$ \\
\hline \multirow[t]{2}{*}{ Malian } & 7 & 8 & 1 & 4 & 20 \\
\hline & $35.0 \%$ & $40.0 \%$ & $5.0 \%$ & $20.0 \%$ & $100.0 \%$ \\
\hline \multirow[t]{2}{*}{ Total } & 54 & 204 & 90 & 34 & 382 \\
\hline & $14.1 \%$ & $53.4 \%$ & $23.6 \%$ & $8.9 \%$ & $100.0 \%$ \\
\hline
\end{tabular}

$\chi^{2}=18.947 ; d f=6 ; P=0.04$

As shown in the table, the majority of respondents $(53.3 \%)$ from Niger Republic indicated that they selected Nigeria as their country of destination because they believed they stood the chance of gaining access to better opportunity in the country, $25.0 \%$ maintained that they chose Nigeria because they had established contacts in the country; close to $15 \%$ linked their choice of Nigeria to her nearness to their country. Less than $10 \%$, however, gave the reason for their choice of Nigeria as resulting from their liking for the country. Similarly, for the respondents from Chad Republic, while close to $59 \%$ indicated that their reason for the choice of Nigeria was due to the belief that they could gain access to better opportunity in the country; $22.4 \%$ submitted that they decided to come to Nigeria because they had contacts in the country; about $14 \%$ linked their reason for the choice of Nigeria to the fact that they liked the country. Furthermore, $40 \%$ of the respondents from Mali decided to come to Nigeria to gain access to better opportunity, while $35 \%$ came to Nigeria because of her nearness to their country.

Also, 20\% adduced their reason to their liking for the country. Only 5\% linked the reason for their choice of Nigeria to the presence of their contacts in Nigeria. In all, it can be established that the major reasons that informed transnational street beggars' choice of Nigeria as their country of destination included quest for better opportunity, the presence of their contacts in the country, the proximity of their countries to Nigeria, as well as their liking for the country. In addition, though the majority of the respondents from the three countries identified better opportunity as the reason that informed their choice of Nigeria, however, a slight disparity was observed in their responses. The 
substantial proportions of Nigeriens $(25.0 \%)$ and Chadians $(22.4 \%)$ claimed that they came to Nigeria because they had contact(s) in the country, while a considerable proportion of the Malians (35.0\%) stated that they selected Nigeria because of her nearness to their country. The observed difference in the reasons given was demonstrated in the significant value of the chi-square $\left(\chi^{2}\right.$ $=18.947, \mathrm{P}<0.05)$ in table 3 . The responses of the respondents covered in the in-depth interviews further corroborated the above quantitative data. In the words of a respondent:

I have been living here since the time of Babangida. Do you think it is because I like Nigeria? No, it is because of the need for survival, this place is better than Niger Republic because we have access to food and water that are lacking in Niger. The government of our country and even your President Jonathan know we are here but they are not ready to help us. (Nigerien Male Transnational Street Beggar/IDI/Kara Area, Ibadan)

The above narrative shows that the problem of transnational street begging in Nigeria is not a recent phenomenon. This respondent had been conducting street begging in Nigeria as a means of survival since the regime of General Ibrahim Babangida, a former Nigeria Head of State, who ruled the country between 1985 and 1993. Also, his response suggests that both the government of his country of origin (Niger Republic) and country of destination (Nigeria) were not doing enough to alleviate their condition. Another respondent stated thus:

I decided to come because of certain problems. To earn a living in Mali is difficult for me and my family. I came to Nigeria to solicit alms temporarily. My plan is to get as much money as possible and then go back to my country to take care of my family. (Malian Female Transnational Street Beggar/IDI/ Obalende Motor Park, Lagos)

The submission of this respondent indicates that the lack of access to basic necessities of life as a result of poverty was the driving force that informed her decision to migrate from Mali to Nigeria for the purpose of alms solicitation. She planned to take temporary residence in Nigeria and to return to her country later after her condition of livelihood might have improved. In the words of another respondent:

We are from Telemsis, but some of us are from Jemkins in Niger Republic. We came to solicit alms in Nigeria because of the problems in Niger Republic; there is food and water shortage in our communities because there was lack of rainfall. (Nigerien Female Transnational Street Beggar/IDI/Agbowo, Ibadan) 
Essentially, the position of this particular respondent was similar to those given by the other two discussed above. From her account, it is clear that some of the transnational street beggars from Niger Republic migrated to Nigeria to solicit alms to counter problems of drought and famine that had ravaged some communities in their country.

The above findings show that Nigeria is susceptible to the continual influx of transnational street beggars from some neighbouring countries, who believe they can improve their standard of living by coming to the country to solicit alms. Swanson (2005) also observed a similar pattern among rural women and children from the Andes who migrated to Ecuador and Colombia for survival needs. In the same vein, the Friends-International and UN Inter-Agency Project (2006) also observed the influx of foreign beggars to Bangkok, Thailand from some neighbouring impoverished countries. Also, it is necessary to note that the desire for a better condition of living has been identified as one of the most important factors promoting internal street begging in Nigeria (Adedibu and Jelili, 2011; Aderinto, Akinwale, Atere and Oyenuga, 2007; National Council for the Welfare of the Destitute, 2001). These findings have further brought to bear the relevance of anomie-strain to this study.

\section{Cross-tabulation of Reasons for Leaving Home-Country and Reasons for the Choice of Nigeria}

To further buttress the discussion, a cross-tabulation of transnational street beggars' reason(s) for leaving home-country and reasons for their choice of Nigeria as country of destination was done. Table 4 presents the results. As evidenced in the table, there was a difference in respondents' responses relating to their reasons for leaving their home countries and why they came to Nigeria. Although regardless of the reasons given for their emigration, better opportunity was identified by most (53.4\%) of the respondents as influencing their choice of Nigeria as the country of destination. However, there was an observed disparity in their responses. 
Table 4: Reasons for Leaving Home-Country and Reasons for the Choice of Nigeria

\begin{tabular}{|c|c|c|c|c|c|}
\hline \multirow{2}{*}{$\begin{array}{l}\text { Reasons for } \\
\text { leaving } \\
\text { home-country }\end{array}$} & \multicolumn{4}{|c|}{ Reasons for the choice of Nigeria } & \multirow[b]{2}{*}{ Total } \\
\hline & $\begin{array}{l}\text { Nearness to } \mathrm{m} \\
\text { country }\end{array}$ & $\begin{array}{l}\text { Better } \\
\text { opportunity }\end{array}$ & $\begin{array}{l}\text { Presence of } \\
\text { contacts }\end{array}$ & I like Nigeria & \\
\hline Drought & $\begin{array}{l}13 \\
3.4 \%\end{array}$ & $\begin{array}{l}61 \\
16.0 \%\end{array}$ & $\begin{array}{l}31 \\
8.1 \%\end{array}$ & $\begin{array}{l}14 \\
3.7 \%\end{array}$ & $\begin{array}{l}119 \\
31.2 \%\end{array}$ \\
\hline Famine & $\begin{array}{l}13 \\
3.4 \%\end{array}$ & $\begin{array}{l}89 \\
23.3 \%\end{array}$ & $\begin{array}{l}20 \\
5.2 \%\end{array}$ & $\begin{array}{l}9 \\
2.4 \%\end{array}$ & $\begin{array}{l}131 \\
34.3 \%\end{array}$ \\
\hline $\begin{array}{l}\text { Poverty and } \\
\text { War }\end{array}$ & $\begin{array}{l}11 \\
2.9 \%\end{array}$ & $\begin{array}{l}35 \\
9.2 \%\end{array}$ & $\begin{array}{l}21 \\
5.5 \%\end{array}$ & $\begin{array}{l}6 \\
1.6 \%\end{array}$ & $\begin{array}{l}73 \\
19.1 \%\end{array}$ \\
\hline $\begin{array}{l}\text { Drought and } \\
\text { Famine }\end{array}$ & $\begin{array}{l}17 \\
4.5 \%\end{array}$ & $\begin{array}{l}19 \\
5.0 \%\end{array}$ & $\begin{array}{l}18 \\
4.7 \%\end{array}$ & $\begin{array}{l}5 \\
1.3 \%\end{array}$ & $\begin{array}{l}59 \\
15.4 \%\end{array}$ \\
\hline Total & $\begin{array}{l}54 \\
14.1 \%\end{array}$ & $\begin{array}{l}204 \\
53.4 \%\end{array}$ & $\begin{array}{l}90 \\
23.6 \%\end{array}$ & $\begin{array}{l}34 \\
8.9 \%\end{array}$ & $\begin{array}{l}382 \\
100.0 \%\end{array}$ \\
\hline
\end{tabular}

$\chi^{2}=30.147 ; d f=9 ; P=0.000$

Unlike in the other three push factors (famine, poverty and war, drought and famine) where liking for Nigeria was the least reason given by the respondents as responsible for their choice of Nigeria as their country of destination, the smallest proportion of the respondents $(3.4 \%)$ that mentioned drought as the cause of their emigration identified nearness of Nigeria to their country of origin as the factor that influenced their selection. The observed difference was further established in the significant value of the chi-square analysis $\left(\chi^{2}=\right.$ $30.147 ; \mathrm{P}<0.05)$ in table 4.

\section{Conclusion}

The push and pull factors of transnational street begging were the central focus of this paper. Findings indicated that drought, famine, poverty and war were the major reasons that accounted for the decisions of transnational street beggars to embark on migration for the purpose of engaging in alms solicitation. Also, transnational street beggars selected Nigeria as their country of destination as a result of four major reasons which included: better opportunity, the presence of their contacts in the country, the proximity of their country of origin to Nigeria, and their liking for Nigeria. It is considered highly imperative to urgently find a lasting solution to the influx of transnational street beggars into Nigeria because it has further aggravated the incidence of street begging, which has already become a social problem in the country. 
Firstly, the Federal Government of Nigeria is urged to put in place a mechanism through which refugees who are genuinely in need can be helped and/or distinguished from immigrants who has permanently taken to street begging as their means of livelihood. Secondly, officials of the Nigeria Immigration Service and personnel of National Agency for the Prohibition of Trafficking in Person and Other Related Matters (NAPTIP) should step up their strategy by developing a mechanism through which the network of traffickers bringing people to Nigeria for the purpose of alms solicitation can be broken. In addition, the Ministry of Women Affairs, Social Welfare and Community Development and other relevant government agencies are urged to be more proactive in the discharge of their responsibilities by developing measures that would be geared towards preventing Nigerians from engaging in street begging. This step will go a long way in addressing the problem of transnational street begging in Nigeria given that that migrant beggars will find it difficult to solicit alms in the country if their local counterparts are not available on the streets.

\section{References}

Adedibu, A.A. and Jelili, M.O. (2011) Package for Controlling Street Begging and Rehabilitating Beggars and the physically challenged in Nigeria: Paper for Policy Consideration. Global Journal of Human Social Science, 11: 17-24.

Adedibu, A.A. and Jelili, M.O. (2012) Characteristics and Types of Beggars in Nigerian Cities: Implications for Public Policy. Centerepoint Humanities Edition, 14: 144-167.

Adedokun, O.A. (2003) The rights of migrant workers and members of their families: Nigeria. International migration and multicultural policies section. UNESCO series of country reports in the ramification of the UN convention on migrants.

Adewuyi, S.A. (2000) Socio-cultural Determinants of Street Begging in Northern Nigeria: the Case of Sokoto. Ph.D. Thesis. Dept. of Sociology. University of Ibadan, Nigeria.

Aderinto, A.A.; Akinwale, A.A.; Atere, A. and Oyenuga, S.A. (2007) Correlates and Hazards of Street Begging: A Qualitative Study of AbleBodied Female Beggars in Ibadan and Lagos, Nigeria. Unilag Sociological Review, viii: 1-20.

Afolayan, A.; Ikwuyatum, G.; Abejide, O. (2010) Dynamics of International Migrant Traders in Nigeria. Preliminary Field Report Submitted to University of Oxford under the McArthur Project on Global Migration and Human Mobility Programme: African Perspective on Human Mobility Programme.

Ahamdi, H. (2010) A study of beggars' characteristics and attitude of people towards the phenomenon of begging in the city of Shiraz. Journal of Applied Sociology, 39: 135-148. 
Cherneva, I. (2011) Trafficking for Begging: Old Game, New Name. Amazon Books.

Cooke, M. and Horn, M. (2001) A Question of Begging: A study of the extent and nature of beggary in the City of Melbourne. Hanover Welfare Services, Melbourne.

Demewozu, W. (2005) Begging as a Means of Livelihood: Conferring with the Poor at the Orthodox Religious Ceremonial Days in Addis Ababa. African Study Monograph, 29: 185-191.

Fawole, A.O.; Ogunkan, D. and Omoruan, A. (2011) The Menace of Begging in Nigerian Cities: a Sociological Analysis. International Journal of Sociology and Anthropology, 3(1): 9-14.

Federal Office of Statistics (2001) National Modular Child Labour Survey Country Report. ILO/SIMPOC.

Federal Government of Nigeria (2007) Federal Republic of Nigeria Official Gazette. Lagos: Federal Government Press, 24: 175-198.

Friends-International and UN Inter-Agency Project (2006) The Nature and Scope of Foreign Child Beggars Issue (especially as related to Cambodian Child Beggars) in Bangkok. United Nations Inter-Agency Project to Combat Human Trafficking in the Greater Mekong Sub-Region.

Ibrahim, O.F. (1997) Religion and Politics: A View from the North. Transition Without End: Nigerian Politics and Civil Society Under Babangida. L. Diamond, A. Kirk-Greene and O. Oyediran (eds.), Ibadan: Vantage Publishers. 509-534.

Igbinovia, P.E. (1991) Begging in Nigeria. International Journal of Offender Therapy and Comparative Criminology, 35: 21-33.

Lynch, P. (2005) Understanding and responding to begging (Australia). Melbourne University Law Review. Retrieved from July 4, 2011, from http://www.austlii.edu.au/au/journals/MULR/2005/16.html.

National Council for the Welfare of the Destitute (2001) Eradication of Street begging in Kaduna. Macaulay Peace Foundation.

Ojedokun, U. A. (2015) Nature and Dynamics of Transnational Street Begging in Lagos and Ibadan Metropolis, Nigeria. PhD. Thesis. Dept. of Sociology, University of Ibadan, Nigeria.

Osagbemi, M.O. and Adepetu, A.A. (1999) Street Begging in Jos Metropolis: Causes and Policy Implications. Journal of Environmental Sciences, 3: 55-69.

Swanson, K. (2005) Begging for Dollars in Gringopampa: Geographies of Gender, Race, Ethnicity and Childhood in the Ecuadorian Andes. DPhil Thesis, University of Toronto.

The Punch. (2012) Nigerian Beggars Arrested in Ghana, Deported. The Punch, Jan. 9.

Veale, A. (1993) Study on Street Children in Four Selected Towns of Ethiopia. Cork: University College Press. 
The Nigerian Journal of Sociology and Anthropology Vol. 13 no. 2

Vold, G. and Bernard, T. (1986) Theoretical Criminology ( $3^{\text {rd }}$ Ed.) Oxford University Press.

Williams III, F. and McShane, M. (1999) Criminological Theory. Prentice Hall Upper Saddle River, New Jersey. 